\title{
Lipids and pigment-protein complexes of photosynthetic apparatus of Deschampsia antarctica Desv. plants under UV-B radiation
}

\author{
N. Yu. Taran, V. O. Storozhenko, N. B. Svietlova, N. M. Topchiy ${ }^{1}$ \\ Educational and Scientific Center «Institute of Biology», National Taras ShevchenkoUniversity of Kyiv \\ 64/13, Volodymyrska Str., Kyiv, Ukraine, 01601 \\ ${ }^{1} \mathrm{M}$. G. Kholodny Institute of Botany, NAS of Ukraine \\ 2, Tereshchenkivska Str., Kyiv, Ukraine, 01601 \\ vstoro@ukr.net
}

\begin{abstract}
Aim. To investigate structural and functional modifications of major components of photosynthetic membranes of endemic antarctic species $D$. antarctica under $U V-B$ radiation. Methods. For quantitative determination of photosynthetic membrane components we used Arnon's method (for chlorophylls and carotenoids); separation of carotenoids was carried out by Merzlyak's method; polar lipids were isolated by Zill and Harmon method in modification of Yakovenko and Mihno; glycolipids separation and identification we carried out by Yamamoto method; and sulfoquinovosyl diacylglycerol content was determined by Kean method. The separation, disintegration and determination of pigment-protein complexes of chloroplasts were carried out by Anderson method. Authenticity of differences between the mean arithmetic values of indices was set after the Student criterion. Differences were considered as reliable at $p \leq 0.05$. Results. We determined structural and functional changes in lipids, carotenoids and pigment-protein complexes at the photosyntetic apparatus level in D. antarctica plants un$\operatorname{der} U V-B$ radiation. Conclusions. Adaptation of D. antarctica plants to $U V-B$ radiation is accompanied by a cascade of physiological and biochemical rearrangements at the level of photosynthetic apparatus, manifested as the changes in pigment, lipid and pigment-protein complexes content.
\end{abstract}

Keywords: Deschampsia antarctica, UV-B radiation, photosynthetic apparatus.

Introduction. $D$. antarctica Desv. is the only native species of Poaceae found in Antarctica. These plants are naturally adapted to the cold maritime Antarctic climate and high level of natural UV-B [1-4]. The radiation may result in the damage of the genetic system and cell membranes, and affect several metabolic processes. Many authors noted that the action of UV-B radiation on plants caused the reduction of biomass, leaf area, growth rate, and photosynthesis [5, 6]. UV-B radiation influenced the plant development not only at the physiological and biochemical levels, but also at the genetic one [7].

There was observed the growth inhibition of $D$. antarctica plants at Palmer station at the Antarctic Peninsula under conditions of Antarctic solar UV-B in com-

(C) Institute of Molecular Biology and Genetics, NAS of Ukraine, 2012 parison with the plots, where solar UV-B radiation was filtered out [8]. Low temperature, high light (illumination) increased the degradation of ozonosphere. It caused enhancement of UV-B radiation level and induced the intensive formation of reactive oxygen species (ROS). Carotenoids, tocopherols and ascorbate are known to protect the photosynthetic apparatus from ROS [9-13].

Besides, there were noted the changes of fluorescence parameters and content of pigments [6], lipids [14] and pigment-proteins complexes [15] in plants under UV-B radiation. Therefore we that investigation of these parameters is expedient to explain the mechanisms of $D$. antarctica plant resistance to UV-B radiation.

Materials and methods. Photosynthetic tissues of D. antarctica plants selected from territories of Antarctic islands were investigated. Control and experimental 

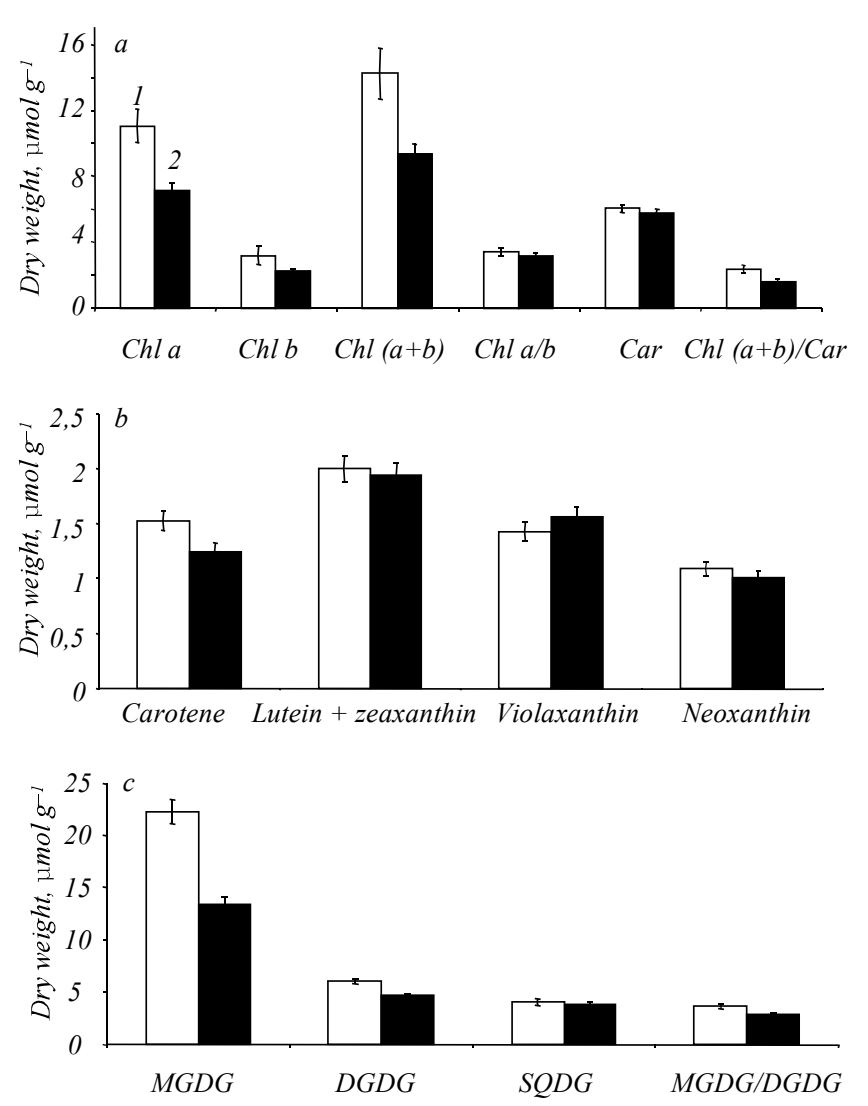

Fig. 1. The content of pigments $(a)$, xanthophylls $(b)$ and glycolipids (c) in leaves of $D$. antarctica plants under UV-B radiation: 1 - control; 2 - UV-B

plants were grown under conditions of constant temperature $\left(10^{\circ} \mathrm{C}\right)$, relative humidity $(60 \%), \mathrm{CO}_{2}$ concentration of $330 \mathrm{ppm}$ and daily illumination by luminescent lamps (L 30W/77, Fluora, 450-650 nm) for 10 days $\left(23 \mathrm{~W} / \mathrm{m}^{2}\right.$, photoperiod $\left.16 \mathrm{~h}\right)$.

The experimental plants were grown under the same conditions, but on the fifth day of growing they were irradiated by UV-B for $20 \mathrm{~h}$ in five expositions $(4 \mathrm{~h}$ in every light period). The UV-B lamp with absorption filter (TL 20BB/12RS («Philips», USA), 280-300 nm) was used for illumination of plants. The dose of UV-B radiation was $6.17 \mathrm{~kJ}^{-2} \mathrm{~m}^{-1}$. The distance from the source of illumination to plants was $10 \mathrm{~cm}$. The pigment content in leaves was determined according to Arnon [16]. The separation of carotenoids was carried out by TLC method [17]. Polar lipids were isolated according to Zill and Harmon method [18] in modification of Yakovenko and Mihno [19]. Glycolipids were separated by TLC and content of monogalactosyl diacylglycerol (MGDG) and digalactosyl diacylglycerol (DGDG) was determined by densitometring TLC plates [20]. Content of sulfoquinovosyl diacylglycerol (SQDG) was determined according to Kean [21].

Separation of thylakoid membranes was carried out in nondenaturing polyacrylamide gel for their disintegration [22]. Content of chloroplast pigment-protein complexes was determined by Anderson method [23].

The experiments were fourfold reproduced; authenticity of differences between the mean arithmetic values of indices was set after the Student's criterion. Differences were considered as reliable at $\mathrm{p} \leq 0.05$.

Results and discussion. The significant changes in photosynthetic pigment composition in leaves of $D$. antarctica plants under UV-B radiation were noted. It induced degradation of chlorophylls (Chls) a, b and $\beta$-carotene. However, the $\mathrm{Chl} \mathrm{a} / \mathrm{b}$ ratio, lutein + zeaxanthin $(\mathrm{Lu}+\mathrm{Zea})$, violaxanthin (Vio) and neoxanthin (Neo) pools were unchanged. The total content of carotenoids (Cars) in D. antarctica plants under UV-B light was also stable.

The molar Chls/Cars ratio was lower in plants under UV-B radiation (1.62) in comparison with control one (2.36) (Fig. 1, $a, b$ ). The Chls/Cars ratio is an important characteristic of the pigment complex. Our data agree with the results of other authors which showed that total $\mathrm{Chl}$ concentration was significantly lower in the plants grown under UV-B radiation [24].

UV-B radiation induces the decrease in content of two galactolipids, MGDG and DGDG, in photosynthetic membranes by 40 and $22 \%$, respectively. At the same time MGDG/DGDG ratio decreased by $28 \%$ (Fig. 1,c). SQDG content was unchanged in these conditions. The ratios between MGDG and xanthophylls in leaves are important characteristics of adaptation of lipid-pigment complexes. In particular, the $\mathrm{MGDG} /(\mathrm{Lu}+$ + Zea) and MGDG/Vio ratios decreased by $38 \%$ and $45 \%$, respectively, under UV-B action (Fig. 2).

The distribution of $\mathrm{Chl}$ in pigment-protein complexes (CP) of plants under UV-B radiation was presented in Table. The percentage of $\mathrm{Chl}$ in pigment-protein complexes of photosystem I (PSI) (CP1a + CP1) increased by $22 \%$ in chloroplasts of irradiated plants. UV-B radiation induced the decrease in percentage of $\mathrm{Chl}$ by $34 \%$ in photosystem II (PSII) reaction centre complexes. It was proved, that PSII in photosynthetic apparatus is the most susceptible part to UV-B radiation [25]. These data indicate a direct disruption of PSII re- action 


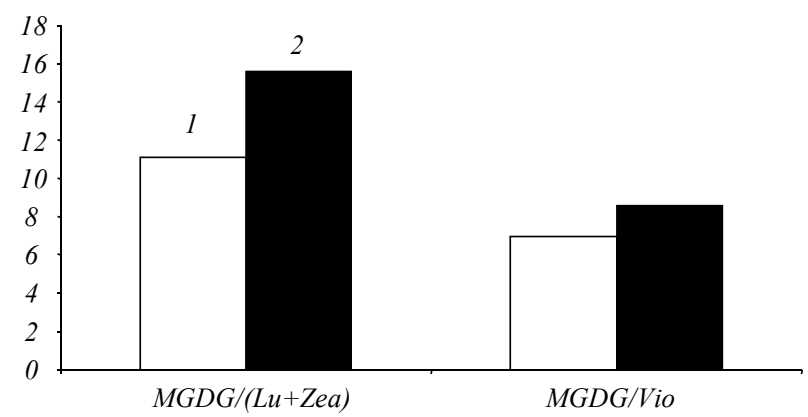

Fig. 2. MGDG/(Lu + Zea) and MGDG/Vio ratios in leaves of $D$. antarctica plants under UV-B radiation (2); 1 - control

Distribution of chlorophyll in the pigment-protein complexes of thylakoids (data presented as means \pm SEM)

\begin{tabular}{l|c|c}
\multirow{2}{*}{$\begin{array}{c}\text { Pigment-protein } \\
\text { complexes and their } \\
\text { ratios }\end{array}$} & \multicolumn{2}{|c}{ Chlorophyll content in the gel, \% } \\
\cline { 2 - 3 } CP1a + CP1 & $15.10 \pm 0.41$ & UV-B \\
LHCP1 & $11.10 \pm 0.69$ & $11.89 \pm 0.34$ \\
CPa & $8.53 \pm 0.31$ & $5.67 \pm 0.17$ \\
LHCP3 & $28.11 \pm 0.21$ & $27.43 \pm 0.22$ \\
Free pigment & $37.16 \pm 1.18$ & $35.71 \pm 0.78$ \\
LHCP1/LHCP3 & $0.40 \pm 0.03$ & $0.43 \pm 0.06$ \\
LHCP1 + LHCP3 & $39.22 \pm 0.48$ & $39.32 \pm 0.25$ \\
\hline
\end{tabular}

centers in leaves of UV-B irradiated plants. The relative amount of oligomeric (LHCP1) and monomeric (LHCP3) forms did not changed under UV-B radiation. Total relative amount of the main $\mathrm{Chl} \mathrm{a} / \mathrm{b}$-protein complex LHCII (sum of its oligomeric and monomeric forms, LHCP1 + LHCP3) was similar in control and in UV-B irradiated plants (Table).

We obtained experimental results, which argue for degradation of $\beta$-carotene in carotenoid pool of leaves of irradiated plants (Fig. 1, $b$ ). $\beta$-Carotene is localized in antenna and reaction centers of PSII. Quenching of triplet state of the primary donor $\left({ }^{3} \mathrm{P}_{680}\right)$ and deoxidation of the oxidized form $\left(\mathrm{P}_{680}{ }^{+}\right)$play an important role in photoprotection. Singlet oxygen $\left({ }^{1} \mathrm{O}_{2}\right)$ and triplet excited chlorophyll $\left({ }^{3} \mathrm{Ch} 1^{*}\right)$ are quenched also by $\beta$-carotene [26-30]. The protection mechanism of photosynthetic apparatus against ${ }^{1} \mathrm{O}_{2}$ leads to the destruction of $\beta$-carotene molecules [31-34].

Under UV-B radiation the decrease in non-bilayer lipid content induces the decrease of MGDG/DGDG ratio in chloroplast membranes and chlorophyll-protein complexes. Therefore, photosynthetic membranes are more susceptible to UV-B radiation. The similar data were obtained in our previous investigations of wheat plants response to heat stress [35]. In our previous publications the dependence between the decrease in MGDG content and the stable content of Vio and Zea in leaves of drought resistant cultivars of Triticum aestivum L. under conditions of drought stress was described for wheat plants [36].

Stable SQDG content against the background of galactolipids decrease in photosynthetic membranes can be considered as an adaptive reaction. It is known, that SQDG provides the maintenance of normal functional state of the PSII reaction center [37]. Therefore, it is possible to presume, that under conditions of UV-B radiation SQDG may support optimum conditions for light phase of photosynthesis. It is established, that the changes in the ratios of different lipid groups, induced by various stress factors are the reflection of a passive adaptation. An active adaptation is associated with the intensity of fatty acids desaturation [33, 38, 39].

Under UV-B radiation MGDG content decreased whereas xanthophyll pool was unchanged. The decrease in $\beta$-carotene content may influence the thylakoid membrane fluidity and activate free radical oxidation of lipids that leads to a decrease in MGDG and DGDG content.

Our data coincide with the results of Sakaki [38], who found out the pigment and lipid (mainly MGDG) decrease at the oxidative stress caused by ozone action. However, the anionic lipid content was stable during the whole exposition period. UV-B action upon $D$. antarctica plants induced the photoinhibition process (degradation of D1 protein of PSII reaction centre) [14]. It is possible that SQDG localized on the surface of the native $\mathrm{D} 1 / \mathrm{D} 2$ heterodimers stabilizes it at stress conditions [40, 42].

UV-B action causes different responses including functional changes and changes of pigment-protein content in photosynthetic apparatus [43]. Pigment-protein composition in chloroplasts treated by UV-B radiation changed. Especially, the content of Chl in pigment-protein complexes of PSI (CP1a $+\mathrm{CP} 1)$ increased (by $22 \%$ ), while it decreased (by $34 \%$ ) in pigment-proteins complexes of PSII reaction centre. As it has been above mentioned PSII is known as the most susceptible part of the photosynthetic apparatus to UV-B radiation [25] that affects both the donor and acceptor sides of 
PSII. Inhibition of PSII electron transport after UV-B irradiation was studied in isolated spinach PSII membrane particles, using low-temperature EPR spectroscopy and chlorophyll fluorescence measurements. There were noted inhibition of oxygen evolution, decline of variable chlorophyll fluorescence and degradation of D1 protein in reaction center after UV-B radiation action [43].

Thus, we described the structural changes at the level of photosynthetic apparatus of endemic antarctical plant $D$. antarctica under the action of UV-B radiation. The results of our work are essential for deeper understanding of adaptation mechanisms of this unique antarctical plant under stress conditions.

Conclusions. Adaptation of $D$. antarctica plants to UV-B radiation is accompanied by a cascade of physiological and biochemical rearrangements at the photosynthetic apparatus level manifested as the changes in pigment, lipid and pigment-protein complex composition. It may be associated with genetically determined resistance of this species to the prolonged influence of UV-B radiation in Antarctic region.

\section{Н. Ю. Таран, В. О. Стороженко, Н. Б. Свєтлова, Н. М. Топчій}

Ліпіди і комплекси пігмент-білок на рівні фотосинтетичного апарату у рослин Deschampsia antarctica за умов ультрафіолетового випромінювання

\section{Резюме}

мета. Дослідження структурних і функціональних модифікацій головних компонентів фотосинтетичних мембран ендемічного антарктичного виду D. antarctica за умов жорсткого ультрафіолетового випромінювання. Методи. Кількісне визначення компонентів фотосинтетичних мембран проводили за методом Арнона (для хлорофілів $і$ каротиноїдів), розділення каротиноїдів - за методом Мерзляка, виділення полярних ліпідів - за методом Зілла $i$ Хармона з модифікацією Яковенка і Міхно, розділення гліколіпідів та їхня ідентифікація - за методом Ямамото, а їхній аналіз - за допомогою програми «Total lab», вміст сульфохіновозилдіацилглічеролу визначали за методом Кіна. Розділення $і$ визначення комплексів пігмент-білок хлоропластів здійснювали методом Андерсон. Достовірність різниці між значеннями середнього арифметичного знаходили за критерієм Ст 'юдента. Різниию вважали достовірною при значенні $p \leq 0,05$. Результати. Встановлено структурні та функиіональні зміни ліпідів, каротиноїдів і комплексів пігмент-білок на рівні фотосинтетичного апаpamy у рослин D. antarctica за умов УФ-В випромінювання. Висновки. Адаптація рослин D. antarctica до впливу жорсткого ультрафіолетового випромінювання супроводжується каскадом фізіологічних і біохімічних перебудов на рівні фотосинтетичного апарату, пов'язаних зі змінами вмісту пігментів, ліпідів $і$ комплексів пігмент-білок.

Ключові слова: Deschampsia antarctica, УФ-В випромінювання, фотосинтетичний апарат.
Н. Ю. Таран, В. О. Стороженко, Н. Б. Светлова, Н. М. Топчий

Липиды и комплексы пигмент-белок на уровне

фотосинтетического аппарата у растений Deschampsia antarctica в условиях ультрафиолетового излучения

\section{Резюме}

Цель. Исследование структурных и функииональных модификаиий главных компонентов фотосинтетических мембран эндемического антарктического вида D. antarctica в условиях жесткого ультрафиолетового излучения. Методы. Количественное определение главных компонентов фотосинтетических мембран проведено по методу Арнона (для хлорофиллов и каротиноидов), разделение каротиноидов - по методу Мерзляка, выделение полярных липидов - по методу Зилла и Хармона с модификацией Яковенко и Михно, разделение гликолипидов и их идентификаџия - по методу Ямамото, а их анализ - с помощью программы «Total lab», содержание сульфохиновозилдиацилглицерола определяли по методу Кина. Разделение и определение комплексов пигмент-белок хлоропластов осуществляли методом Андерсон. Достоверность различий между значениями среднего арифметического находили по критерию Стьюдента. Различия считали достоверныли при значении $p \leq 0,05$. Результаты. Установлены структурные и функциональные изменения в содержании и соотночении липидов, каротиноидов и комплексов пигмент-белок на уровне фотосинтетического аппарата растений $D$. antarctica 8 условиях УФ-В излучения. Выводы. Адаптация растений $D$. antarctica к воздействию жесткого ультрафиолетового излучения связана с каскадом физиологических и биохимических перестроек на уровне фотосинтетического аппарата, связанных $c$ изменениями в содержании пигментов, липидов и комплексов пигмент-белок.

Ключевые слова: Deschampsia antarctica, УФ-В излучение, фотосинтетический аппарат.

\section{REFERENCES}

1. Alberdi M., Bravo L. A., Gutierrez A., Gidekel M., Corcuera L. $J$. Ecophysiology of Antarctic vascular plants // Physiol. Plan.2002.-115, N 4.-P. 479-486.

2. Lewis-Smith R.. I. The enigma of Colobanthus quitensis and Deschampsia antarctica in Antarctica // Antarctic biology in a global contextn / Eds A. H. L. Huiskes, W. W. C. Gieskes, J. Rozema et al.-Leiden: Backhuys Publ., 2003.-P. 234-239.

3. Xiong F. S., Mueller E. C., Day T. A. Photosynthetic and respiratory acclimation and growth response of Antarctic vascular plants to contrasting temperature regimes // Am. J. Bot.-2000.87, N 5.-P. 700-710.

4. Xiong F.S., Ruhland C.T., Day T.A. Photosynthetic temperature response of the Antarctic vascular plants Colobanthus quitensis and Deschampsia antarctica // Physiol. Plant.-1999.-106, N 3.P. 276-286.

5. Environmental effects of ozone depletion: 1998 Assessment // UNEP.-Nairobi, 1998.-P. 1-209.

6. Szollosi E., Veres S., Kanalas P., Olah V., Solti A., Sarvari E., Meszaros $I$. Effects of UV-B radiation and water stress on chlorophyll fluorescence parameters and activity of xanthophyll cycle in leaves of sessile oak (Quercus petraea) seedlings // Acta Biol. Szegediensis.-2008.-52, N 1.-P. 241-242.

7. Ambasht N.K., Agrawal M. Influence of supplemental UV-B radiation on photosynthetic characteristics of rice plants // Photosynthetica.-1997.-34, N 3.-P. 401-408.

8. Day T.A., Ruhland C.T. Grobe C.W., Xiong F. Growth and reproduction of Antarctic vascular plants in response to warming and 
UV radiation in the field // Oecologia.-1999.-119, N 1.-P. 2435.

9. Edge R., McGarvey D. J., Truscott T. G. The carotenoids as antioxidants - a review // J. Photochem. Photobiol. B.-1997.-41, N 3.-P. 189-200.

10. Gould K.S., McKelvie J, Marckham K.R. Do anthocyanins function as antioxidants in leaves? Imaging of $\mathrm{H}_{2} \mathrm{O}_{2}$ in red and green leaves after mechanical injury // Plant Cell Environ.-2002.-25, N 10.-P. 1261-1269.

11. Latowski D., Kostecka-Gugala A., Strzalka K. Effect of the temperature on violaxanthin de-epoxidation: Comparison of the in vivo and model systems // Russ. J. Plant Physiol.-2003.-50, N 2.-P. 173-177.

12. Muller-Moule P., Havaux M., Niyogi K. K. Zeaxanthin deficiency enhances the high light sensitivity of an ascorbate-deficient mutant of Arabidopsis // Plant Physiol.-2003.-133, N 2.P. 748-760.

13. Palozza P., Krinsky N. L. Antioxidant effects of carotenoids in vivo and in vitro: an overview // Methods Enzymol.-1992.-213, N 2.-P. 403-420.

14. Kettunen R., Tyystjarvi E., Aro E. M. Degradation pattern of photosystem II reaction center protein D1 in intact leaves. The major photoinhibition-induced cleavage site in $\mathrm{D} 1$ polypeptide is located amino terminally of the DE loop // Plant Physiol.1996.-111, N 4.-P. 1183-1190.

15. Moorthy P., Kathiresan K. Effect of UV-B radiation on photosynthetic reactions in Rhizophora apiculata // Plant Growth Regul.-1999.-28, N 1.-P. 49-54.

16. Arnon D. Copper Enzymes in isolated chloroplasts. Polyphenoloxidase in Beta vulgaris // Plant Physiol.-1949.-24, N 1.P. $1-15$.

17. Merzlyak M.N. Densimetric determination of carotenoids in plants in thin layers of «Silufol» plates // Nauchnye doklady Vysshey shkoly. Biologicheskie nauki.-1978.-1.-P. 134-138.

18. Zile L. P., Harmon E. A. Lipids of photosynthetic tissue. I. Silicic acid chromatography of the lipids from whole leaves and chloroplasts // Biochim. Biophys. Acta.-1962.-57, N 3.P. $573-583$.

19. Yakovenko G.M., Mihno A.I. Method of isolation and separation lipids and chloroplasts by types // Fiziol. i Biochim. Kult. Rast.-1971.-3, N 6.-P. 651-656.

20. Yamamoto $H$. High speed quantitative assay on TLC/HPTLC plates. Instrumental HPTLC.-New York: Ed. W. Bertch \& R. Raser. 1980.- 367-384p.p.

21. Kean E. L. Rapid, sensitive spectrophotometric method for quantitative determination of sulfatides // J. Lipid Res.-1968.-9, N 3.-P. 319-327.

22. Anderson J. M., Melis A. Localization of different photosystems in separate regions of chloroplast membranes // Proc. Natl Acad. Sci. USA.-1983.-80, N 3.-P. 745-749.

23. Anderson J. M. P-700 content and polypeptide profile of chlorophyll-protein complexes of spinach and barley thylakoids // Biochim. Biophys. Acta.-1980.-591, N 1.-P. 113-126.

24. Liu L., Xu S., Woo K.C. Solar UV-B radiation on growth, photosynthesis and the xanthophyll cycle in tropical acacias and eucalyptus // Environ. Exp. Bot.-2005.-54, N 2.-P. 121-130.

25. Bornman J. F. New trends of photobiology: Target sites of UV$\mathrm{B}$ radiation in photosynthesis of higher plants // J. Photochem. Photobiol. B.-1989.-4, N 2.-P. 145-158.

26. Cogdell R. J., Frank H. A. How carotenoids function in photosynthetic bacteria // Biochim. Biophys. Acta.-1987.-895, N 2.P. 63-79.

27. Stroch M., Spunda V., Kurasova I. Non-radiative dissipation of absorbed excitation energy within photosynthetic apparatus of higher plants // Photosynthetica.-2004.-42, N 3.-P. 323-337.
28. Telfer A., Bishop S.M., Phillips D., Barber J. Isolated photosynthetic reaction center of photosystem II as a sensitizer for the formation of singlet oxygen. Detection and quantum yield determination using a chemical trapping technique // J. Biol. Chem.1994.-269, N 18.-P. 13244-13253.

29. Telfer A., De Las Rivas J., Barber J. $\beta$-Carotene within the isolated photosystem II reaction centre: photooxidation and irreversible bleaching of this chromophore by oxidised P680 // Biochim. Biophys. Acta.-1991.-1060, N 1.-P. 106-114.

30. Telfer A., Dhami S., Bishop S. M., Phillips D., Barber J. $\beta$-Carotene quenches singlet oxygen formed by isolated photosystem II reaction centers // Biochemistry.-1994.-33, N 48.P. $14469-14474$

31. Barber J. Molecular basis of the vulnerability of Photosystem II to damage by light // Aust. J. Plant Physiol.-1994.-22, N 2.P. 201-208.

32. Minkov I. N., Jahoubjan G. T., Denev I. D., Toneva V. T. Photooxidative stress in higher plants // Handbook of plant and crop stress / Ed. M. Pessarakli.-New York: Marcl Dekker, 1999.P. 499-525.

33. Ruban A.V., Berera R., Ilioaia C., van Stokkum I.H.M., Kennis J.T.M., Pascal A. A., van Amerongen H., Rober, B., Horton P., van Grondelle $R$. Identification of a mechanism of photoprotective energy dissipation in higher plants // Nature.-2007.-450, N 7169.-P. 575-578.

34. Strzhalka K., Kostecka-Gugala A., Latovski D. Carotenoids of plants and stress action of environment: the role of modulation of physical properties of membranes by carotenoids // Fiziol. Rast.-2003.-50, N 2.-P. 188-193.

35. Taran N.Yu., Okanenko O.A., Svietlova N.B, Musienko M.M. The influence of heat on glicerolipid content of wheat thylakoids // Dopov. NAN Ukrainy.-2000. N 1.-P. 165-169.

36. Svietlova N. B., Taran N. Yu., Okanenko O. A., Musienko M. M. Carotenoids and glycolipids in adaptive response of winter wheat chloroplasts to drought // Dopov. NAN Ukrainy.-2004.N 2.-P. 192-195.

37. Pick U., Gounaris K., Weiss M., Barber J. Tightly bound sulfolipids in chloroplast $\mathrm{CF} 0-\mathrm{CF} 1 / /$ Biochim. Biophys. Acta.1985.-808, N 3.-P. 415-420.

38. Sakaki T. Photochemical oxidants: toxicity // Responses of plant metabolism to air pollution and global change / Eds L. J. De Kok, I. Stulen.-Leiden: Backhuys Publ., 1998.-P. 117-129.

39. Taran N. Yu., Okanenko A. A., Kosyk O. I. Plant sulfolipid. II. Mutant study and phosphate deficiency // Biopolym. Cell.-2009.-25, N 1.-P. 3-11.

40. De Kruijff B., Pilon R., Hof R., van't Demel R. Lipid-protein interactions in chloroplast protein import-P. 191-208.

41. Vijayan P., Routaboul J.-M., Browse J. A genetic approach to investigating membrane lipid structure and photosynthetic function // Lipids in photosynthesis: structure, function and genetics (Advances in photosynthesis and respiration) / Eds P.-A. Siegenthaler, N. Murata--Amsterdam: Kluwer Acad. Publ., 1998.-Vol. 6.-P. 263-285.

42. Siefermann-Harms D., Ninnerman H., Yamamoto H. Reassemble of solubized chlorophyll-protein complexes in proteolipid particles comparison of monogalactosyldiacylglycerol and two phospholipids // Biochim. Biophys. Acta.-1987.-892, N 3.P. 303-313.

43. Vass I., Sass L., Spetea C., Bakou A., Granotakis D., Petrouleas $V$. UV-B-induced inhibition of photosystem II electron transport studied by EPR and chlorophyll fluorescence. Impairment of donor and acceptor side components // Biochemistry.-1996.35, N 27.-P. 8964-8973. 